\title{
Effect of Storage on the Sensory and Microbial Quality of Blanched and Quick Frozen Jackfruit Samples
}

\author{
T. Bindhya Dhanesh*, S.M. Sasmila Bai, B.G. Akhila, K.P. Shareena and G.K. Rajesh
}

Department of Food and Agriculture Process Engineering, Kellapaji College of Agricultural Engineering and Technology, Kerala Agricultural University, Tavanur, Malappuram, Kerala, India

*Corresponding author

\section{A B S T R A C T}

Jackfruit is considered as heavenly fruit by ancient people of Southern parts of India. It is a rich source of vitamins, minerals and calories and offers numerous health benefits. The

\section{Keywords}

Jackfruit, Blanching, Quick freezing, Modified atmospheric packaging, Sensory analysis, Microbial analysis

Article Info

Accepted: 10 February 2018 Available Online: 10 March 2018 fruit is highly perishable due to its inherent compositional and textural characteristics. Proper postharvest technology for prolonging shelf life is necessary to makes its availability throughout the year. Blanching followed by quick freezing of tender, mature and ripe jackfruit was conducted separately to increase shelf life. Storage studies were conducted using various packaging materials and packaging techniques. In order to standardize a suitable packaging material for the stored products, three packaging materials viz., Low density polyethylene (LDPE), Polypropylene (PP) and aluminum laminates of different gauges were studied. The packaging techniques used were active modified atmospheric packaging (MAP), passive MAP and vacuum packaging. No microbial infestation was found in aluminium laminate. Vacuum packaging and active MAP were found superior than passive MAP. Microbial and sensory analysis was done in every 15 days interval. From the sensory analysis it was confirmed that the samples which were blanched and frozen at $-10^{\circ} \mathrm{C}$ for three hours followed by drying at $60^{\circ} \mathrm{C}$ were the best in aluminium laminate pouches.

\section{Introduction}

Jackfruit is native to the rain forests of Western Ghats of India. It is popularly grown in Southern and Eastern parts of India. People consumed it mostly as a fruit when ripe but also as vegetable in the unripe stage. It is a rich source of vitamins $\mathrm{A}, \mathrm{B}$ and $\mathrm{C}$, potassium, calcium, iron, proteins, and carbohydrates and offers numerous health benefits. The fruit's isoflavones, antioxidants and phytonutrients mean that it has cancer-fighting properties. It is also known to help cure ulcers and indigestion. Jackfruit is good source of vitamins and minerals. Ripe fruit flakes contain carbohydrate, carotene, thiamine, minerals etc. Lectine, a natural protein from fruit is used in cancer treatment. An extract of jackfruit called 'Jacaline' inhibited the growth of HIV infection 'in vitro' (Priya et al., 2014).

In every year, a considerable amount of jackfruit, specially obtained in the glut season (June-July) goes waste both in quality and 
quantity due to lack of proper postharvest technology during harvesting, transporting and storing. Proper postharvest technology for prolonging shelf life is, therefore, necessary. The market potential of jackfruit can be better exploited if the fruits are made available to the consumers in a ready to eat or cook form throughout the year. Development of processing facilities that can undertake primary processing at producers level can greatly increase the consumer acceptance and demand of jackfruit. Technologies like dehydration for preservation of jack flakes need to be standardized and popularized for ensuring availability throughout the year and for avoiding market glut during season. A proper storage technique can definitely contribute towards quality product and fetch better price and thus improve the financial status of the jackfruit growers in the state which perhaps create a positive influence in state and national economy.

\section{Materials and Methods}

\section{Test sample}

Tender, mature and ripe jackfruit procured from the Instructional Farm of Kelappaji College of Agricultural Engineering and Technology, Kerala Agricultural University, Tavanur were the samples selected for study. The outer skins of the fresh jackfruit were peeled off and cut into pieces. Seeds were removed before slicing, in case of mature and ripe jackfruits.

\section{Pre treatments}

\section{Blanching and quick freezing}

Pretreatments such as blanching and quick freezing were conducted prior to drying to enhance rehydration, prevents discolouration and off flavor development during storage. Conventional method of blanching was conducted in this study. Turmeric powder was mixed with water at the rate of 5 gm per litre to enhance the appearance. The samples were blanched by dipping in turmeric water at $100^{\circ} \mathrm{C}$ for 2 minutes. After blanching, the hot water was drained and the samples were placed on a Whatman No. 4 filter paper to drain the excess water. The blanched samples were frozen by placing in a deep freezer at temperatures of $-10^{\circ} \mathrm{C}$ for $1 \mathrm{hr}$. The frozen samples were then allowed to thaw at room temperature.

The jackfruit samples after thawing were dried in a RRLT-NC drier (Regional Research Laboratory Trivandrum-Natural Convection dryer) as shown in Plate2. Drying was accomplished by vaporizing the water that is contained in the food. In the improved natural convection driers named RRLT-NC drier, the hot air is generated separately outside the drier chamber and is conveyed upwards through a separate duct by natural convection. Drying process was stopped when the moisture content of the samples was about $12 \% \pm 0.5$ (w.b.).

\section{Storage studies of dried jackfruit}

In order to standardize the suitable packaging material to enhance the shelf life of dried jackfruit, the samples were put in bags made of Low-density polyethylene (LDPE 400 gauges) Polypropylene (PP 250gauges) and aluminium foil (100 gauge).

The dried samples (tender, mature and ripe jackfruit) were packed in the three different plastic materials. The packets were sealed using the hand sealing machine. The storage study was conducted for six months.

A sample of $10 \mathrm{~g}$ each was packed in the above said packages. The various packaging techniques conducted were 1) Massive MAP 2) Active MAP and 3) Vacuum packaging. 
Vacuum packaging machine was employed for active MAP and vacuum packaging whereas ordinary sealing machine was used for passive MAP. The packed samples were kept inside a wooden box. For every 15 days interval, the packets were examined for the microbial attack. Pictures are depicted in Plate 2 to 4.

\section{Sensory evaluation}

The stored jackfruit samples were rehydrated and after cooking were taken for sensory evaluation by a panel of 10 expert judges from Kelappaji College of Agricultural Engineering and Technology, KAU. Different attributes that is appearance, colour, texture, flavour and taste were observed by a 5-point hedonic rating scale. The samples were arranged in tables with specific codes. The scale was easily understood by each of the panelist and their response was converted to numerical values for computation purposes. Final results were obtained by calculating the average of all the marks given by panelist.

\section{Microbial analysis}

A portion of the infected samples were scraped with a blade and placed in a test tube containing distilled water and shaken well. It becomes turbid if the sample were infected with bacteria. An expert could easily observe through microscope the bacterial attack if the infected samples are placed on a slide with a few drops of water. The scraped samples were also put in a polythene bag with few drops of water. After blowing air the bag were tied and kept undisturbed. The bag would be completely filled with mould growth if the samples were infected with fungus. If the preliminary tests were positive further tests for identifying the species were carried out as follows. Serial dilutions test were conducted to assess microbial population (David and Frankhausar 2010). Nutrient agar and potato dextrose media were used for bacteria and fungus respectively. For bacteria it was diluted up to $10^{-6}$ and for fungus up to $10^{-3}$. Pour platting was done. The number of colonies of each kind was counted. This number was then multiplied by the dilution factor to find the total number of cells per $\mathrm{ml}$ of the original sample.

\section{Statistical analysis}

Analysis for the product appearance, texture, taste, flavour, colour were performed individually using one way ANOVA and Tukey's post- ANOVA test.

\section{Results and Discussion}

\section{Sensory evaluation}

The results of sensory evaluation showed that the samples which were blanched for two min. and freezed at $-10^{\circ} \mathrm{C}$ for three hour followed by drying at $60^{\circ} \mathrm{C}$ had good acceptability scores at different intervals of storage period in aluminium laminates. Pritty and Sudheer (2012) optimized the blanching process for tender 'Varikka' jack fruit. Blanching process at $100^{\circ} \mathrm{C}$ for one minute using $0.3 \%$ citric acid as preservatives was found to be the best in terms of sensory attributes (texture and colour) and enzyme inactivation. Similar observations seen in the present study were reported by Gulzar and his coworkers (2018) with regard to the sensory qualities of blanched mango slices of Chaunsa and Fajri varities.

\section{Microbial analysis}

The dried jackfruit samples were kept for storage. The samples packed in 200 gauge polypropylene with passive MAP were found to be infested by various micro-flora and micro-organisms after three weeks of storage. The same infection was also found in LDPE after five weeks of storage. 


\section{Plate.1 RRLT-NC drier}

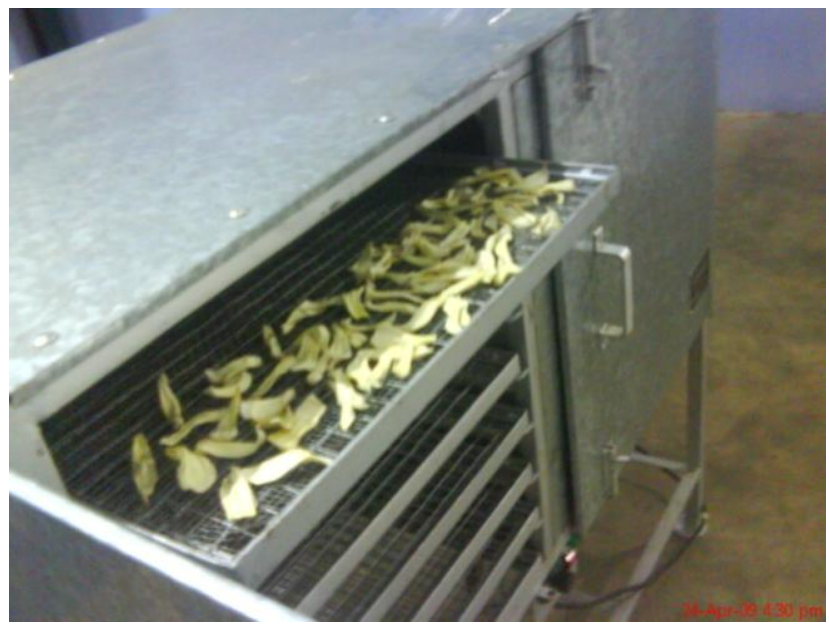

Plate.2 Vaccum packed LDPE

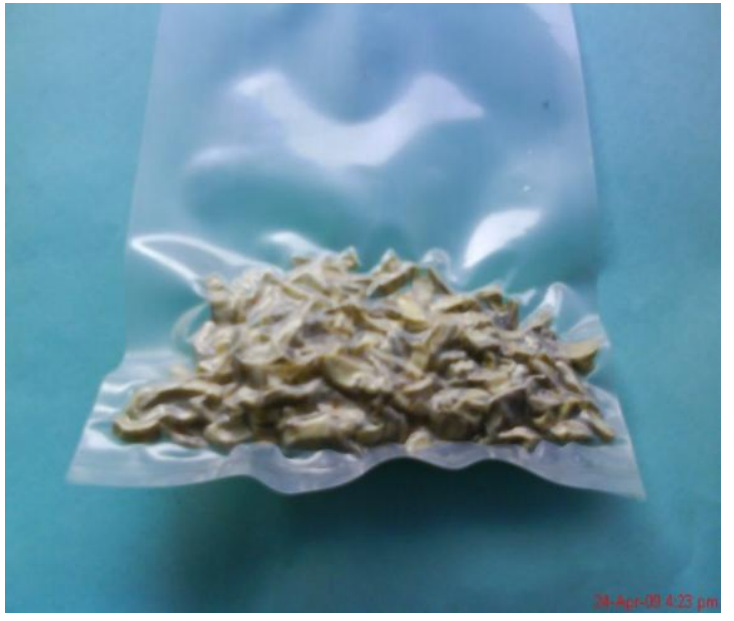

Plate.3 Nitrogen flushed polypropylene

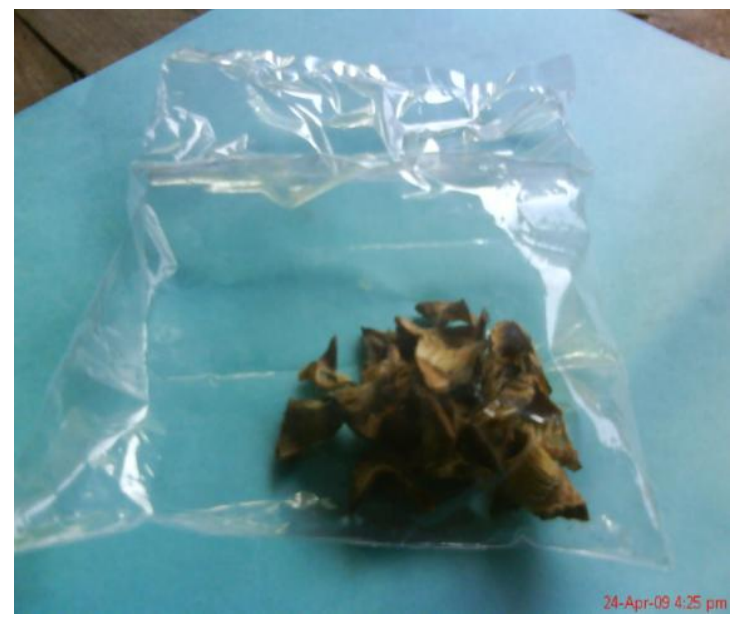

Plate.4 Aluminium laminate

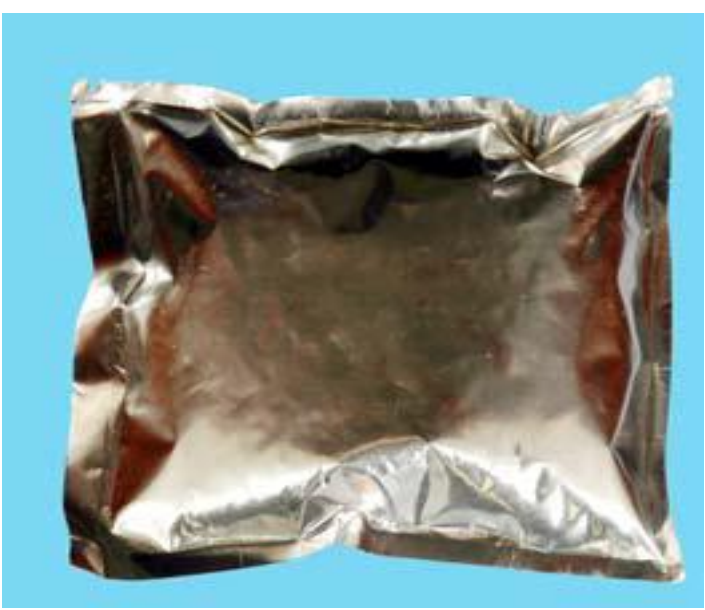


Preliminary studies conducted at the Product Analysis Lab of Department of Post-Harvest Technology of this college showed that the samples were infected with both bacteria and fungi. In order to confirm the result and for further investigations, the infected samples were conducted for identification. It was observed that the samples packed with poly propylene having 200 gauge were infected with both fungus and bacteria. The attack was faster in PP and LDPE. This may be due to the impermeable nature of the packed material. No microbial infestation was found in aluminum laminate.

Vacuum packaging and active MAP were found superior than passive MAP. Pereira and coworkers (2004) evaluated the quality of minimally processed guavas (Psidium guajava L.), osmotically dehydrated and packed under passive modified atmosphere during 24 days of storage at $5^{\circ} \mathrm{C}$.

It was found that Modified atmosphere packaging (MAP) in polyethylene terephthalate (PET) containers had a strong influence on color preservation and weight loss of the guavas. Osmotically dehydrated guavas stored in MAP showed good microbial conditions during storage.

The further investigation on the type of organisms present in the samples were conducted Population of different fungal species were observed like Rhizopus (0.40\%), Aspergillus niger (Black)- $0.80 \%$, Aspergillus (Yellow)$51.2 \%$ and Aspergillus (Green)- $47.5 \%$

Storage studies were conducted using various packaging materials and packaging techniques. In order to standardize a suitable packaging material for the stored products, three packaging materials viz., LDPE, PP and aluminum laminates of different gauges were studied. The packaging techniques used were active MAP, passive MAP and vacuum packaging. The microbial attack was faster in PP and LDPE packets. No microbial infestation was found in aliminium laminate. Vacuum packaging and active MAP were found superior than passive MAP. From the sensory analysis it was confirmed that the samples which were blanched for two minutes and frozen at $-10^{\circ} \mathrm{C}$ for three hours followed by drying at $60^{\circ} \mathrm{C}$ were the best when packed in aluminium laminates.

\section{References}

David, B. and Frankhausar. 2010. Pour plate technique for bacterial enumeration http://biology.clc.uc.edu/frankhauser/Lab s/Microbiology/Meat_Milk/Pour_Plate.ht $\mathrm{ml})$

Gulzar A., Ahmed M., Qadir M.A., Shafiq M.I., Ali S., Ahmad I. and Mukhtar M.F. 2017. Effect of blanching techniques and treatments on nutritional quality of dried mango slices during storage. Polish J. Food Nutr.Sci. 68(1): 171-180

Pereira LM, Rodrigues ACC, Sarantópoulos CIGL, Junqueira VCA, Cunha RL, Hubinger MD. 2004. Influence of modified atmosphere packaging and osmotic dehydration of minimally processed guavas. J Food Sci. 69(4):172177.

Pritty, S.B. and Sudheer, K.P. 2012. Optimization of blanching process for tender jack fruit. Indian J. Dairy Bio Sci. 23: 14-21.

Priya, S.D., Devisunetra, T., Mathala, J.G., Thangam, M., and Singh, P.N. 2014. A guide on jackfruit cultivation and value addition. Technical Bulletin No.41, ICAR (RC), Goa.

\section{How to cite this article:}

Bindhya Dhanesh, T., S.M. Sasmila Bai, B.G. Akhila, K.P. Shareena and Rajesh, G.K. 2018. Effect of Storage on the Sensory and Microbial Quality of Blanched and Quick Frozen Jackfruit Samples. Int.J.Curr.Microbiol.App.Sci. 7(03): 913-917. doi: https://doi.org/10.20546/ijcmas.2018.703.107 